\title{
LUNAR1 wt Allele
}

National Cancer Institute

\section{Source}

National Cancer Institute. LUNAR1 wt Allele. NCI Thesaurus. Code C118119.

Human LUNAR1 wild-type allele is located in the vicinity of 15q26.3. This allele, which encodes leukemia-associated non-coding IGF1R activator RNA 1, may be involved in both acute lymphoblastic leukemia and Notch-mediated signaling. 